\title{
EPIDURAL ANAESTHESIA IN PAEDIATRIC SURGERY \\ PRESENT STATUS IN THE HAMILTON GENERAL HOSPITAL
}

\author{
F G Ruston, M D
}

THE uSE of epidural anaesthesia in paediatric surgery has been described in two previous reports ${ }^{12}$ It is the purpose of the present paper to report our experience with this technique in the Hamilton General Hospital since these previous publications, to demonstrate why we feel that this technique has a definite place in paediatric anaesthesia, and to endeavour to erase some of the doubts which have led to the statement in regard to anaesthesia for pyloromyotomies that "the use of epidural anaesthesia remains unconvincing":

The anatomy and physiology of the epidural space have been well described by Bromage, ${ }^{3}$ and will not be repeated here Techniques, drugs, dosage, complicatons, and application will be discussed, with reference to operafions handled by the staff in anaesthesia of the Hamilton General Hospital during the period from 1956 to 1962 inclusive

\section{TECHNIQUe of EPIDURAL BLOCK}

Epidural block may be employed in enther a single dose or a continuous technique Either may be used alone, or combined with general anaesthesia by the inhalation or intravenous routes Prernature and young infants are awake when the block is given, as also are older infants and children if they have untestınal obstruction These latter may receive a sedative dóse of thiopentone sufficient to pacify them without abolishing the glottic reflex Large infants and children are intubated under anaesthesia with thiopentone and a small dose of succinylcholine and are maintaned on nytrous oxide, to which 025 per cent halothane may be added, using a non-rebreathing valve techmique This general anaesthesia is induced before the epidurall black is done in order to ensure the arway during prolonged surgery

The single-dose method is used for prematures and neonates, and for other infants and children when the surgical time is expected to be under two hours The infants, who are awake, are held in a sittung position, with the head supported and the elbows and knees grasped by the assistant, so that the spine is gently flexed Only slight wriggling movement can occur, which is not too troublesome All others are held in the lateral position iBefore the infant is positioned, the desired dose of local anaesthetic solution is drawn up into: a syringe The dose in cubic centimetres equals $1 / 2$ (weight in pounds) $+1 / 2$ or $1 \mathrm{c} \mathrm{c}$ Usually a skin wheal is raised over the site of puncture-L2 and 3, or $\mathbb{L} 3$ and 4 The needle is equipped with projections which and in placing and maintaining it in position while the injertion is being made $\mathrm{A}$ two-inch $\mathrm{No}^{\circ} 22$ gauge Becton, Dickinson Epidural Needle with a Wagner Point ${ }^{5}$ is preferred II also prefer the hanging drop lest to identufy the epidural space It is positive in 85 
per cent and, in spite of an occasional false positive which is mentioned by Biomage, ${ }^{3}$ which will be evident by the greatly increased resistance on the plunger when one tries to carry out the injection, it is by far the most reliable test However, if the drop is not sucked in or does not fluctuate, then the loss of resistance on the plunger of the syringe will identufy the space of course one must be sure, at this spoint, that the dura has not been pierced If fluid escapes from the needle, let a few drops fall on the bare wn ist If these drops are cold, the dura has been spared and it is safe to inject the full dose The patient is placed on a padded board and securely wrapped with a flamnel bandage Patients are closely observed, blood pressures are taken if it is feasible, but experience has shown that pulse, heart sounds, breath sounds, and colour are pretty reliable signs Within five minutes definite abdominal relaxation is present, while the feet can still be moved when simulated (This indicales that there is not spinal anaesthesia) Surgery can be started withm five to ten minutes

The contunuous technique is reserved for large infants and children when the surgical time is expected to exceed two hours The limitung factor is the size of the needle which will go through the interspinous space and still carry the catheter For this reason $\mathbb{I}$ have not attempted to use the Tuohy Needle with the Huber Point I have found that the thin-walled No 18 Becton, Dickinson Needle with the short-bevel Crawford Point can be used in infants over three months of age The patient is usually intubated as mentioned before, and held in the lateral position After preparation, the skin is incised with a scalpel blade at the site of puncture The needle is inserted and angled as much as possible cephalad with the bevel in the same direction When the epidural space is entered, two cubic centumetres of solution are injected in order to act as a cushion agamst the needle point and to produce a space for the cathetes to advance and curve cephalad from the needle point The vinyl-tubing catheter is advanced the length of the stilette and two centimetres further, with the inner curve of the catheter cephalad If the catheter seems to meet an obstruction, the needle is withdrawn a millimetre or two while at the same tume gentle pressure is exerted on the catheter The needle is then carefully withdrawn so that the catheter is not disturbed A small dressing is placed over the entry site and the catheter is securely taped to the back with adhesive The distal end of the catheter $1 s_{w}$ fitted with a hypodermic needle and the total dose is given at once or in divided doses The initial drug may be Carbocame 15 per cent followed by 2 per cent Nesacaine as required The usual supervision is mainlained and an attempt is made to anticipate the waning of relaxation and anaesthesia so that additional increments of solution may be injected

Pre anaesthetic sedation may or may not be given Usually nothing is ordered tor premature and newborn infants, "pylorics" recelve Sodrum Luminal gr $1 / 4$ with atropine gr $1 / 600$ intramuscularly 1 hour preoperatively, others, who have intravenous cut-downs running, recerve atropme only in surtable dorage

\section{APPLiCATION}

Table I shows what was done in Hamilton from 1949 to 1956 and is from a previous report published in $1957^{2}$ It gives some idea of the scope of paediatric 
TABLE I

Lumbar Epidural and Caudal Anaesthrsía, 1949 to 1956 (80 Cases)

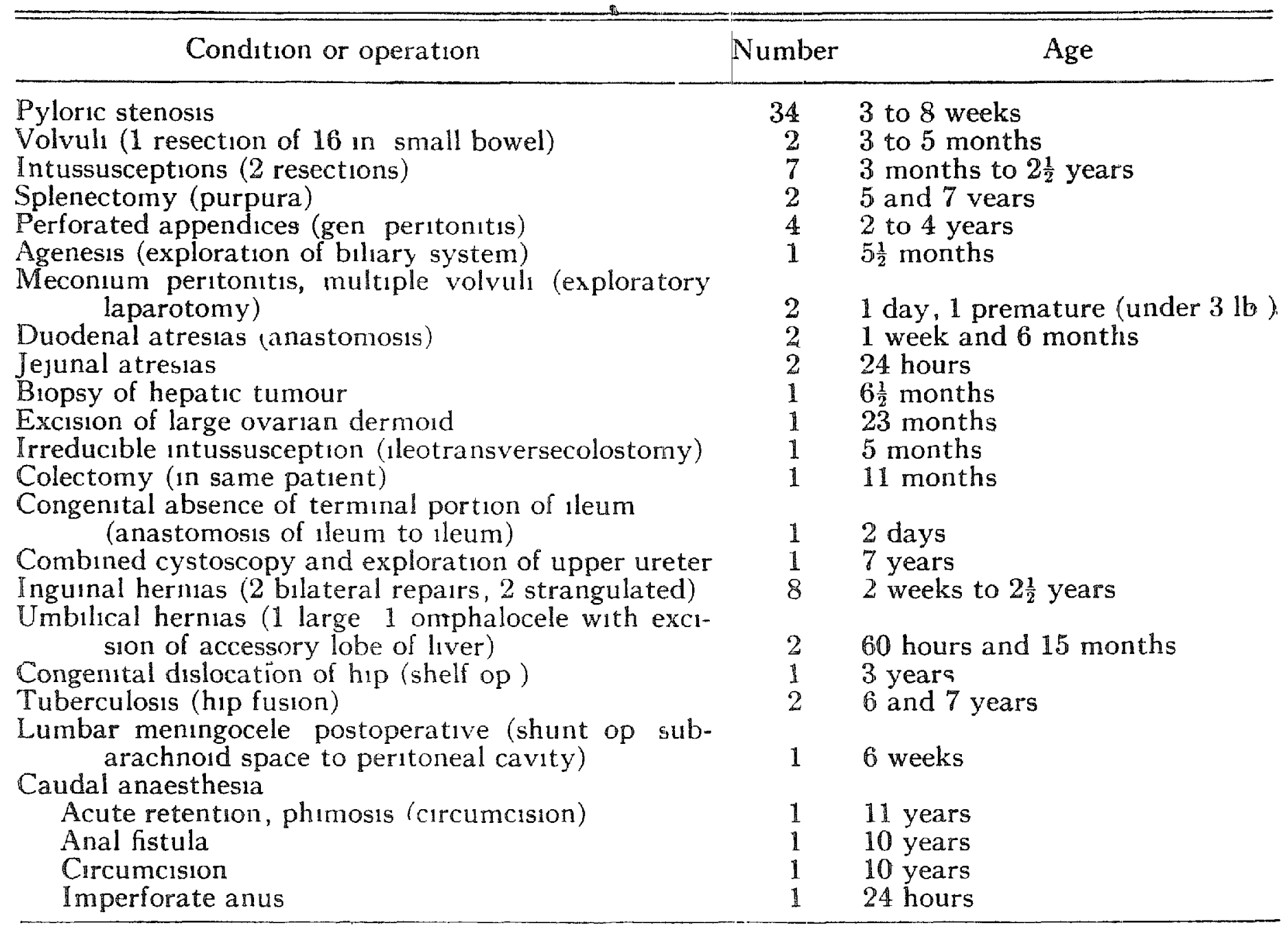

TABLC II

Paddiatric Surtery by Epidural Blor K, 1956 to 1962 INCLUSIVE

\begin{tabular}{|c|c|c|}
\hline & No & Complications \\
\hline Pyloromy otomies & 54 & \multirow[t]{7}{*}{1 pneumona, 1 died } \\
\hline Evisceration & 1 & \\
\hline Hemihepatectomy & & \\
\hline Volvulus & 4 & \\
\hline Close ileostomy & 1 & \\
\hline Duodenal atresias & 3 & \\
\hline Agenesis terminal ileum & 1 & \\
\hline Omphalocele (2 ruptured) & & \\
\hline Primary closure & $\frac{1}{2}$ & \multirow[t]{3}{*}{1 died 5 days po } \\
\hline Intestinal obstruct & 1 & \\
\hline Repair with mesh & 1 & \\
\hline Abdominal perineal resections & & \multirow{4}{*}{1 bronchitis } \\
\hline Hirschsprung's & 4 & \\
\hline Redone & 1 & \\
\hline Imperforate anus & 1 & \\
\hline Pelvic tumour & 1 & \multirow[t]{2}{*}{ Died 18 hours po } \\
\hline Bil pyelostomies & 1 & \\
\hline Hernias & & \multirow{5}{*}{ Both died po } \\
\hline Inguinal & 1 & \\
\hline Diaphragmatic & 2 & \\
\hline Intussusceptions & 10 & \\
\hline & 92 & \\
\hline
\end{tabular}


epidural anaesthesia Since then halothane has become an important agent so that Table II shows a more conservative use of epidurals Table III depicts the anaesthetic techniques used in pyloromyotomies The preponderance of epidurals seen here occurs throughout all abdominal surgery with the exception of hernia reparrs The decrease in the number of pyloromyotomies done is due to the fact that such patients are now admitted also to two other hospitals in the city of Hamilton Table IV shows the local anaesthelics used in pyloromyotomies

TABLE III

Pyloromyotomies at Hamilton General|Hospital, 1956 To 1962 (1953 to 1955 inclusive 1 spinal, 8 general, 26 epidural)

\begin{tabular}{ccc}
\hline Year & General & Epidural \\
\hline 1956 & 4 & 41 \\
1957 & 0 & 15 \\
1958 & 0 & 6 \\
1959 & 0 & 9 \\
1960 & 0 & 5 \\
1961 & 2 & 6 \\
1962 & 1 & \multicolumn{2}{|c}{} \\
& 7 & $b 4$ \\
\hline
\end{tabular}

TABLE IV

Pyloromyotomiss, 1956 to 1962 InCLusive

\begin{tabular}{cccllr}
\hline \multicolumn{1}{c}{ Drug } & & No & & Supplement & No \\
\hline Xylocaine & $2 \%$ & with & $\mathbb{1}$ & $\mathrm{N}_{2} \mathrm{O}$ & 5 \\
Xylocaine & $115 \%$ & $1 / 200,000$ & 22 & Pentothal & 1 \\
Xylocaine & $1 \%$ & epinephrine & 20 & Cyclo & 4 \\
& & & & $\mathrm{~N}_{2} \mathrm{O}$ and cyclo & 3 \\
Nesacaine & $2 \mathrm{c}$ & & $\mathrm{N}_{2} \mathrm{O}$ and fluothane & 5 \\
Carbocaine $1 \%$ & & 5 & $\mathrm{~N}_{2} \mathrm{O}$ & 2 \\
& & 6 & $\mathrm{~N}_{2} \mathrm{O}$ & 2 \\
& & 54 & & 22 \\
\hline
\end{tabular}

Xylocame with $\mathbb{1} / 200,000$ epinephrine has been the most popular but $\mathbb{I}$ now have a preference for Carbocame and Nesacane because they cam be used without epinephrine Nesacane is indicated when the Ramstedt procedure is done by a fast surgeon, for the anaesthetic tume is only thirty-five minutes Carbocaine 1 per cent, or Xylocaine 15 per cent with epunephrune can be depended on for two hours These anaesthetics have been administered by eight of the eleven members of our staff, which explans the diversity of supplement My own preference, is natious oxsde with a loose fittung mask or a mask fitted with a Ruben's Valve, arfd-supplement is resorted to only if the unfant cries when the pylonc tumour is brought up into the incision, for any excessive movement will increase the difficulty of the myotomy This provides analgesia but does not suppress the glotic reflex Table Vrepresents those patuents handled by contunuous epidural block and were done by"me The children wnth intus- 
susception were given a small amount of thropentone as a hypnbtic while the epidural was being injected They could $/$ have been managed by $\backslash$ a single-dose method

TABLE V

Continuous Epidurals, 1959 to 1962

\begin{tabular}{|c|c|c|c|}
\hline Operation & Age & Anaes time & Combined \\
\hline Intussusceptions & $\begin{array}{l}8 \text { months } \\
5 \\
9\end{array}$ & 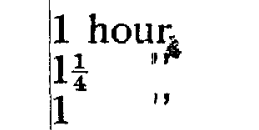 & $\begin{array}{l}\text { Pentothal 2 c c } \\
\text { Pentothal 2 c c } \\
\text { Pentothal 3 c c }\end{array}$ \\
\hline Hemhepatectomy & $9 \quad "$ & 6 hours & \\
\hline $\begin{array}{l}\text { Omphalocele repair } \\
\text { Abd pernneal resect }\end{array}$ & 2 years & 3 & \\
\hline Abd perineal resect & $11 "$ & $B \frac{1}{2}$ & \\
\hline Hirschsprung's & $1_{2}^{\frac{1}{2}} \quad "$ & $\beta_{\frac{1}{2}}^{2}$ & Orotracheal $\mathrm{N}_{2} \mathrm{O}$ \\
\hline Redone & $\begin{array}{l}1 \frac{1}{2} \text { " } \\
11 \text { months } \\
14 \text { " }\end{array}$ & $\begin{array}{ll}2 \frac{1}{2} & " \\
3 \frac{1}{2} & " \\
3 & ",\end{array}$ & and fluothane $025 \%$ \\
\hline Pelvic tumour & 5 & $3 \frac{1}{2}$ & \\
\hline
\end{tabular}

The hemihepatectomy (Figure 1) consisted of mobilizing the hepatic flexure of the colon and exploration of the right perirenal area because of adhesions, but when it was found that the malignant teratoma was confined to the liver, the abdominal incision was extended through the chest to the right eighth intercostal space The diaphragm was cut for access to the vena cava to check bleeding Respirations were controlled to prevent paradoxical breathing The right hepatic lobe and a large wedge of the left lobe were removed while the vena cava and the portal vein were clamped for five minutes Succinylcholne was given intermittently to paralyse the diaphragm durmg its repair Postoperatively the child developed jaundice and seemed to be on the verge of a hepatatic crisis but this did not occur

The infant with omphalocele (Figs 2,3, and 4) had the primary repair done under a single dose and the secondary with a combined continuous epidural This repair was complicated by the presence of the liver and a mass of gut in the omphalocele and a large defect in the abdominal wall, which was closed by Mersilene mesh The block was more difficult because of an accentuated lumbar curve The procedure was accomplished under excellent relaxation, and most important, with constricted, tapelike bowel, and spontaneous respirations

The abdominal perineal resections for Hirschsprung's disease are of some interest One patient had chronic bronchitis from birth and the operation was cancelled several times because of chest infection After operation the chest was a problem Another resection ( $F_{1} g$ ) was a difficult operation because the pathologist was unable to find any normal ganglionic tissue until sections were taken from well up the colon, which resulted in a rather stretched bowel, with precarious blood supply, for it was anchored by the colostomy The anastamosis broke down after eight days (Fig 6) The whole procedure was repeated with the additional transfer of the colostomy-a real surgical problem in a sick child! This child received a minute dose of succinylcholıne to relax spasm of the diaphragm caused by accidental movement of the child's head which 
GH207 R61

\section{MAMHLOON CIVIC HOSPITALS AMABSTHETIC CHARI}

\author{
DATE 19 Sept 60 HOSPITAL NFH
}

PREOPERATIVE DIAGNOSIS Malignant terratuma PROPOSED OPERATION of liver

PROPOSED OPERATION Hepatectomy (hemi-)
John G a mos.

SURGEON Cameron

RECORD OF PHYSICAL EXAMINATION

DATE TIME PULSE 3 BP 100 RESPIRATION TEMPERATURE

PHYSICAL EXAMINATION NEGATIVE EXCEPT FOR THE FOLLOWING

Chest and heart neg. Abdomen distended. Liver at umbilicus. Had

biopsy done at st Joseph's - malignant terratomel of et lobe of liver。 $\mathrm{Hb} .9 .8 \mathrm{G}$ Wt. $18 \mathrm{lbs} 9$ oz.

PRE OPERATIVE SEDATIVE Atrop. gr 1/200 RISK A R D EMERGENCY

ANAESTHETIC AGENTS \& TEC HNIQUES

REMARKS

1 Combined Epldural (continuous) and orotracheal $\mathrm{N}_{2} \mathrm{O}$ and Fluothane

\begin{tabular}{|c|c|c|c|c|c|}
\hline 2 & Nesacaine. & $3 \% 8$ & $\operatorname{ccs}$ & $815 \mathrm{am}$ & Nesacalne $2 \% 5$ ces. 11.40 am. \\
\hline 3 & $n$ & $2 \% 2$ & 11 & $8.20 \mathrm{am}$ & $12.10 \mathrm{pm}$. \\
\hline 4 & "1 & $2 \% 5$ & 11 & $9.00 \mathrm{am}_{0}$ & 1500 b ood during operation. \\
\hline 3 & $" 1$ & $2 \% 5$ & $" 1$ & $9.50 \mathrm{am}$ & 10 ccs. Ca Gluconate \\
\hline TIVE & Position & & & SURGEON & $B 1$, pressure from lt thigh \\
\hline
\end{tabular}

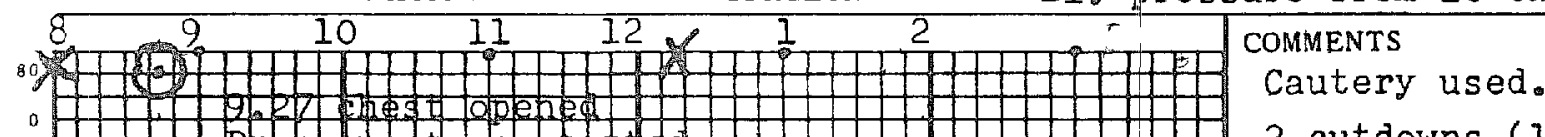

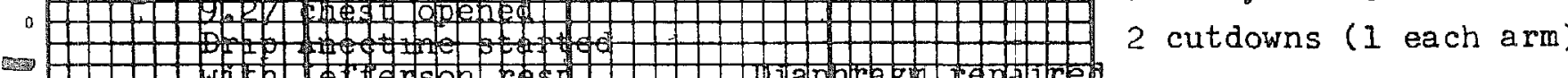

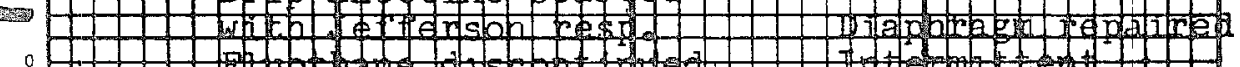

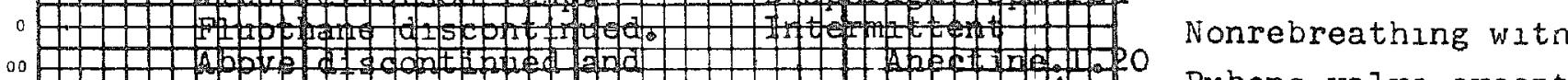

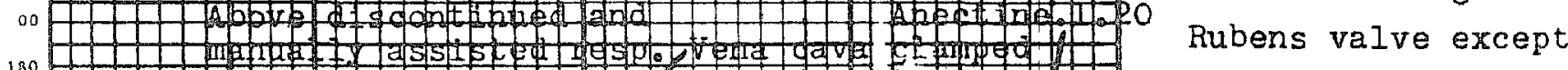

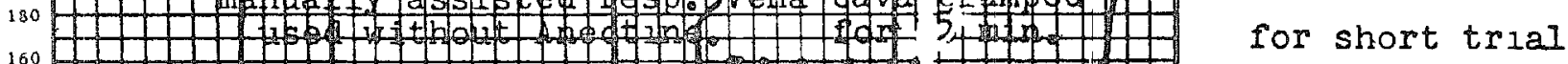

${ }_{140}^{160} 4 \mathrm{H}$ H

:

10840 y

To recovery rm. 2.15

100

(1)

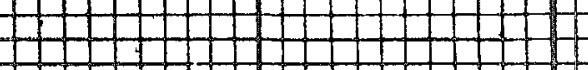

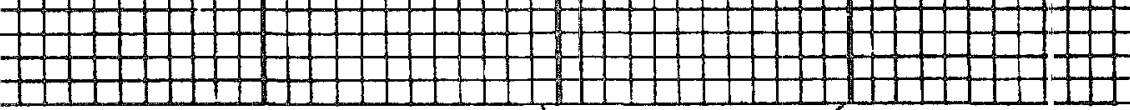

$\mathrm{Z}_{\mathrm{hr}}$

$63 \mathrm{hrs}$

$4 \mathrm{hrg}$

OPERATION PERFORMED RT, \& wedge of It removed.

TOTAL OPERATING TIME $845-210$ DURATION OF ANAESTHETIC $8.00=2.25$

CONDITION ON LEAVING OPERATING ROOY faI $r$

Figure 1

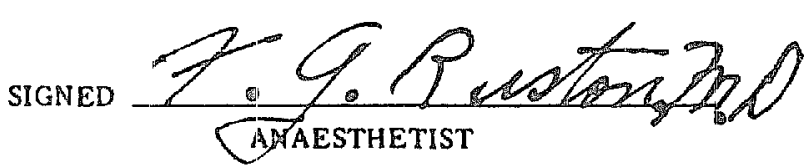

caused it to buck on the endotracheal tube, but abdominal selaxation remamed excellent to the end of operation

The last case of this group had a tumour obstucting the pelvic cavity It was freed from above by an extraperitoneal abdominal incision, but because of the size and adherence to the sacium, a portion of the sacrum was resected 


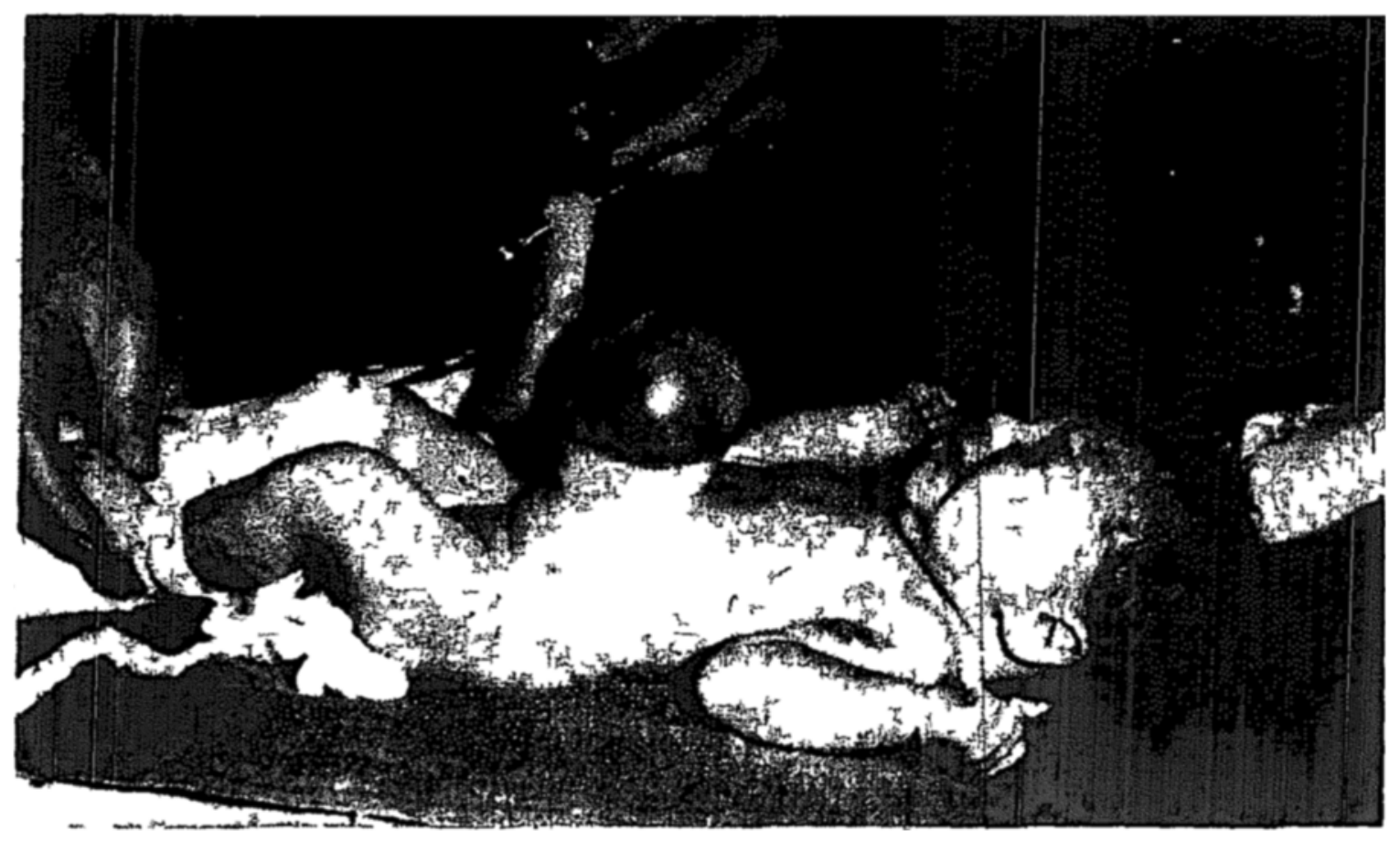

Frgune $\$ 2$ Severe omphalocele containing liver in newborn infant

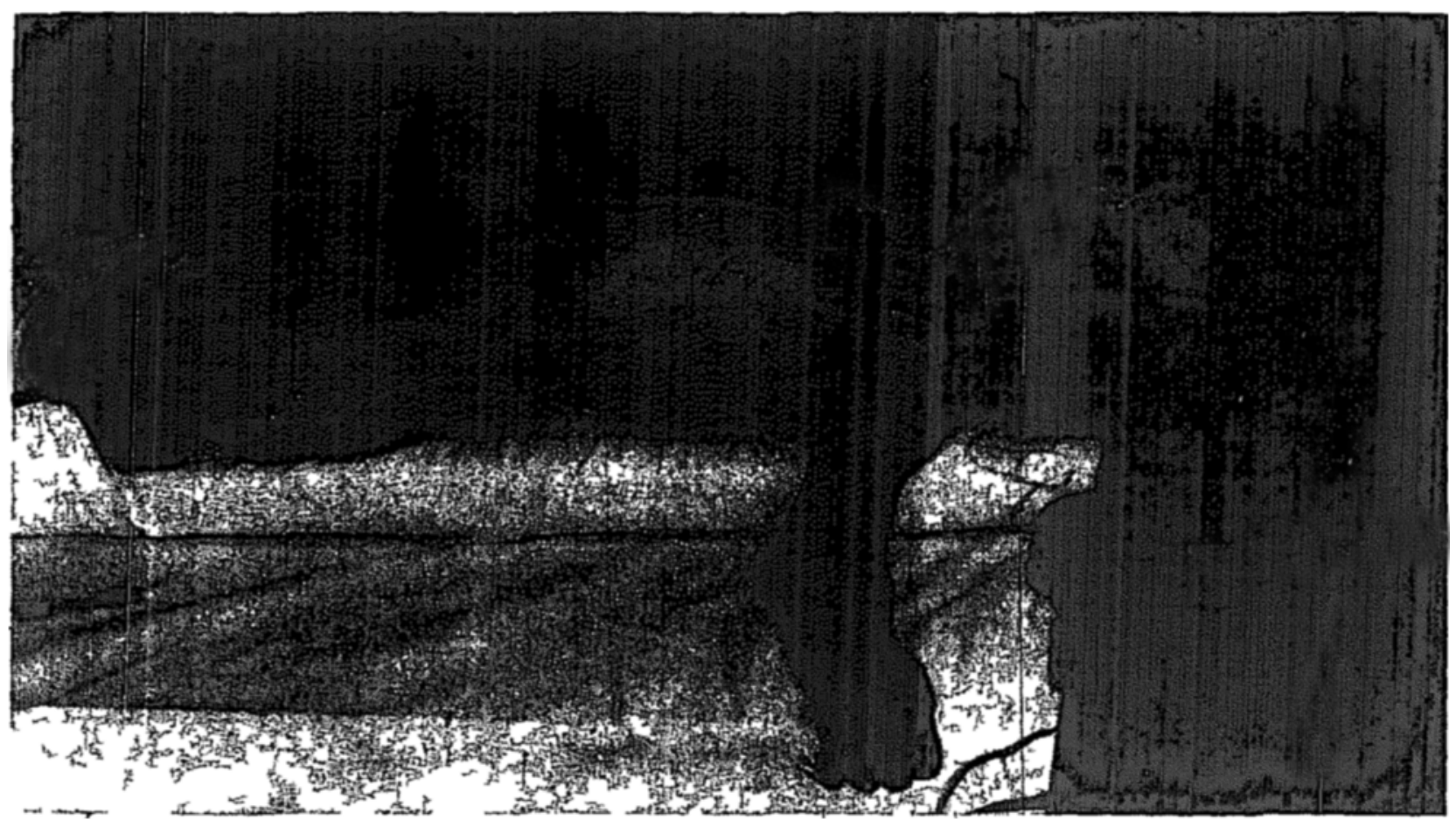

Figune 3 Same pat nt ready for second stage repar-epidural cathet $r$ in place In this case intubation followed epidural block 


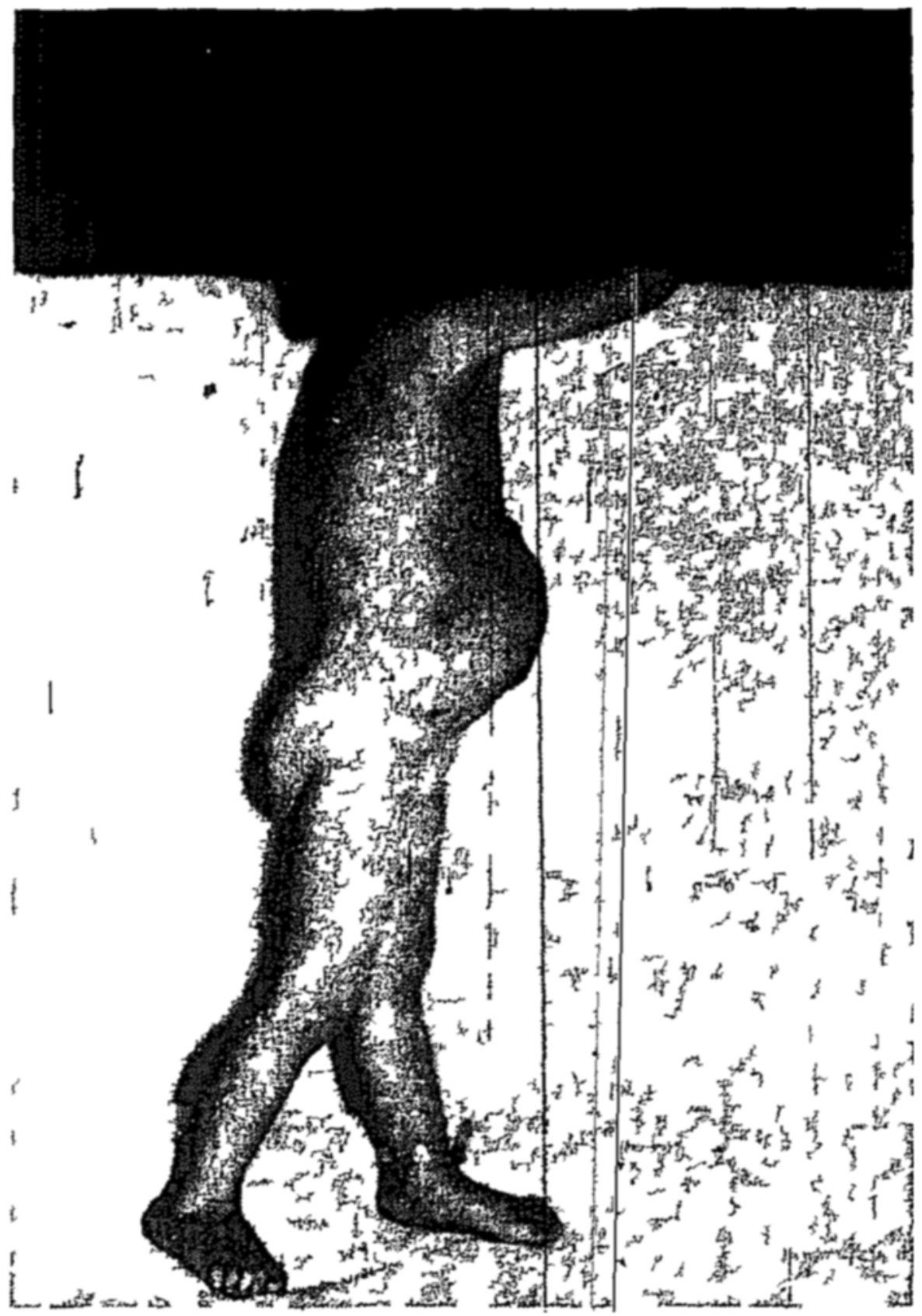

Figure 4 The | New Look following repair with Mersilene mesh

to obtain room to deliver the mass Bleeding was excessive but blood volume was maintained by transfusion The patient died suddenly eighteen hours post operatively Autopsy showed a farrly large collection of blood in spite of con tanuous wound suction there was also a termunal aspiration The pathologist gave some comfort for the tumour was a malignant neuroblastoma

All the operations of this group were done with electrocautery dissection to cut down on incisional bleeding

\section{COMPLICATIONS}

In addution to those already mentioned there were the followng complica tons One infant developed pneumonia after five days followng a Ramstedt procedure but the paediatrician thought it to be from a cross infection $\mathrm{A}$ new born inf int who had projectule vomitng and who showed the typical picture of pyloric stenosis after the ingestion of Lipiodol was found to have only muld pyloric hypertrophy but a myotomy was done The infant died twelve days 
GH207 R61

\section{HAMILTON CIVIC HOSPITALS ANAESTHETIC CHART}

DATE 7 Aug. 62 HOSPITAL NFH
$\frac{\text { PREOPERATIVE DIAGNOSIS Hitschsprung's Dis. }}{\text { PROPOSED OPERATION }}$ Abdominal
perincal pull throujh.

\section{RECORD OF PHYSICAL EXAMINATION}

DATE PIME BULSE

PHYSICAL EXAMINATION NEGATIVE EXCEPT FOR THE FOLLOWING Chest and heart neg.

Admitted two times but operation carcelied because of respiratory

infections. Transverse colostomy at 1 week. Weight 24 Ibs.

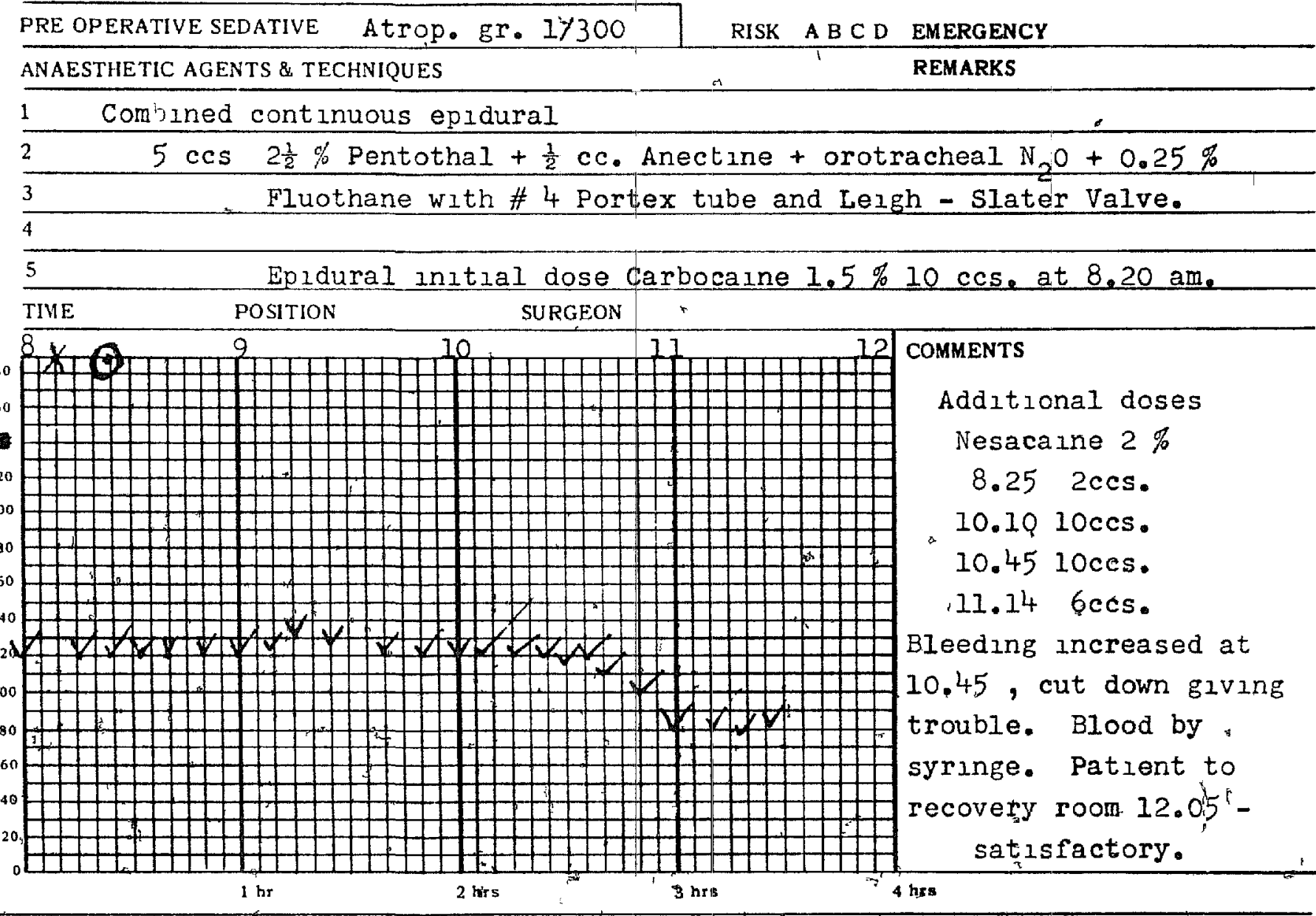

OPERATION PERFORMED

TOTAL OPERATING TIME $3 \frac{1}{2} \mathrm{hrs}$. DURATION OF ANAESTHETIC 4 hrs.

CONDITION ON LEAVING OPERATING ROOM satisfactary

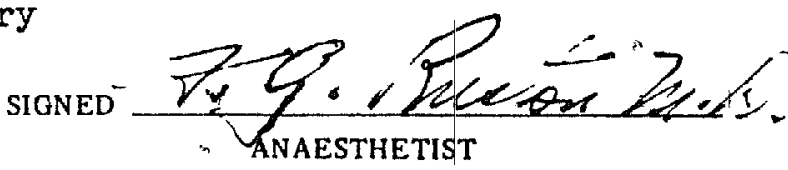

Figuke 5

later and autopsy established that death resulted from congenital bilateral hydronephrosis and hydroureters and a monilal pneumonitss, the latter thought to have arisen from "either vaginitis of the mother or antibiotic therapy given the infant" 
CH207 R61

\section{MAMHTON CIVIC MOSPITALS AMABSTHETIC CMAMT}

DATE

16 Aug 62 Hospital NFH \begin{tabular}{ll}
$\mathrm{HGH}$ \\
\hline
\end{tabular}

PREOPERATIVE DIAGNOSIS Wound dehiscence and oreakdown of anastimosis
PROPOSED OPERATION

Exploration, transfer of colostomy

and re-anastimosis at rectum

RECORD OF PHYSICAL. EXAMINATION

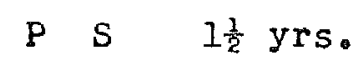

G Cameron

\section{DATF TIME PULSE B P}

PHYSICAL EXAMINATION NEGATIVE EXCEPT FOR THE FOLLOWING

Abdominal perineal pull through for Hirschsprung's on 7 aug. 62.

Eruption of abdominal wound Rectal examination showed breakdown of

PRE OPERATIVE SEDATIVE Atrop. anastimpsis. Weight 241 bs. $1 / 300$ RISK A B C D IMERGENCY

ANAESTHETIC AGENTS \& TECHNIQUES Comolned continuous epi duralREMARKS

1 and orotracheal $\mathrm{N}_{2} \mathrm{O}+0.25 \%$ Fluothane

2

3 Epidural 12 ccs. $1.5 \%$ Carbocalne at $1.10^{\circ} \mathrm{pm}$

4

$5 \quad \frac{1}{2}$ cc Anectine at 2.50 as patient bucked when endotracheal tube

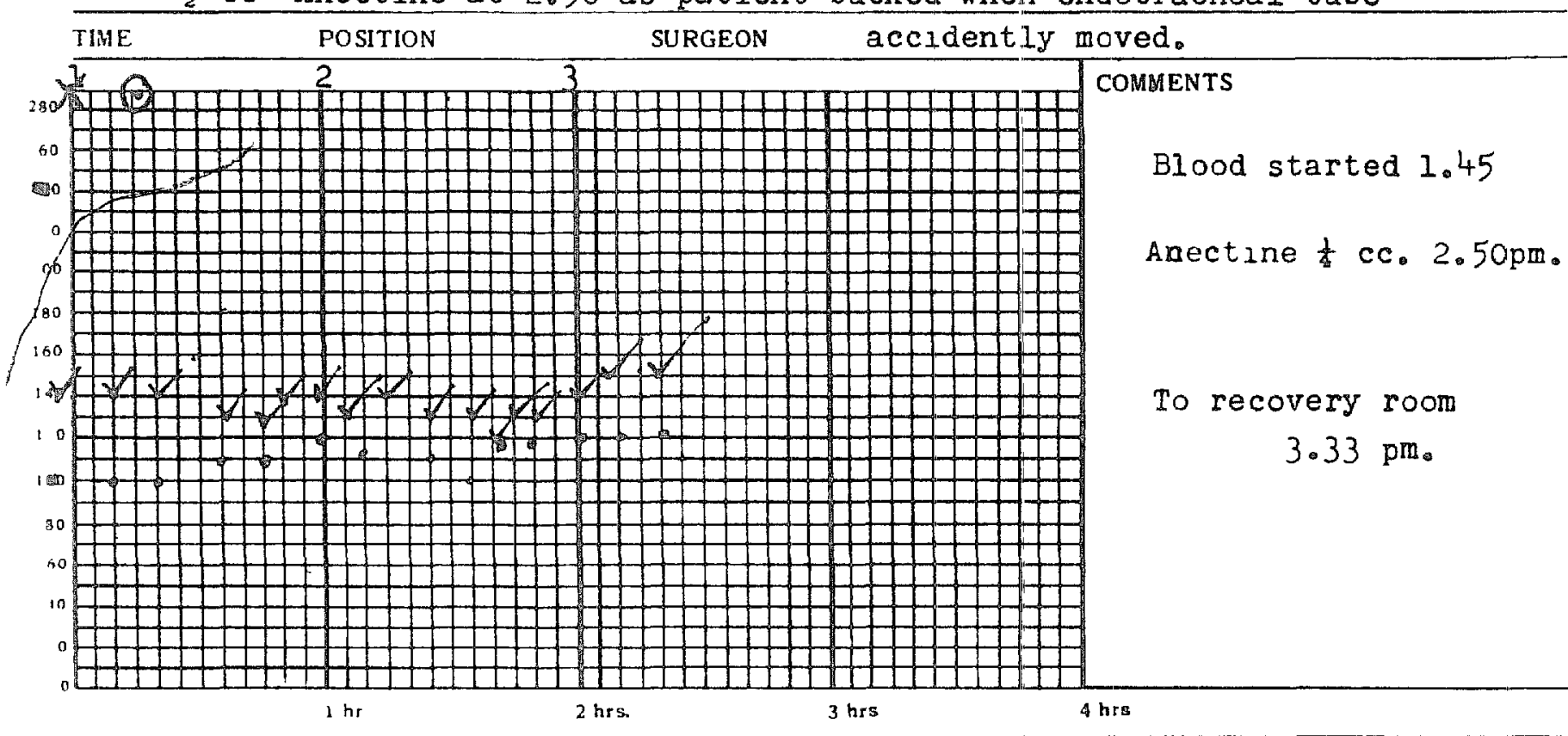

OPERATION PERFORMED

TOTAL OPFRATING TIME 2 hrS。 DURATION OF ANAESTHETIC $2 \frac{\mathrm{l}}{\mathrm{e}} \mathrm{hrs}$

CONDITION ON LEAVING OPERATING ROOM Satisfactory

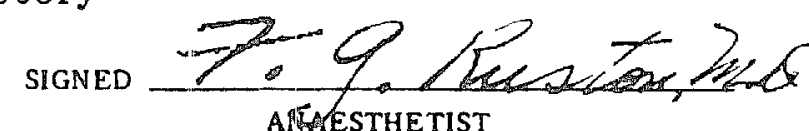

Figuhe 6

A newborm who underwent surgery for an omphalocele died five days postoperatnvely from at cerebral hemorrhage and a congenital heart defect

Both unfants with diaphragmanc hernias died, one from pneumonia and the other from a tear in the lung bud I do beheve that combined epidural block ands in the operation 
There was another death in a nèonate in which epidural anaesthesia was a contributing if not a prequpitating factor The dragnosis was intestnal obstruction in a moribund infant who died immediately after the block had been given before surgery was attempted and on who no autopsy was done

Another complication which does nat appear in the list of operations applies to the continuous technique A secondary repair was scheduled in an infant with a severe omphalocele which had ruptured before burth I had promised to demonstrate the continuous epidural technique This patient had the same lumbar deformity which was observed in the case mentioned earlier The infant was intubated and carried on hitrous oxide and the needle was inserted without difficulty into the epidurdl space but when the catheter was advanced it met

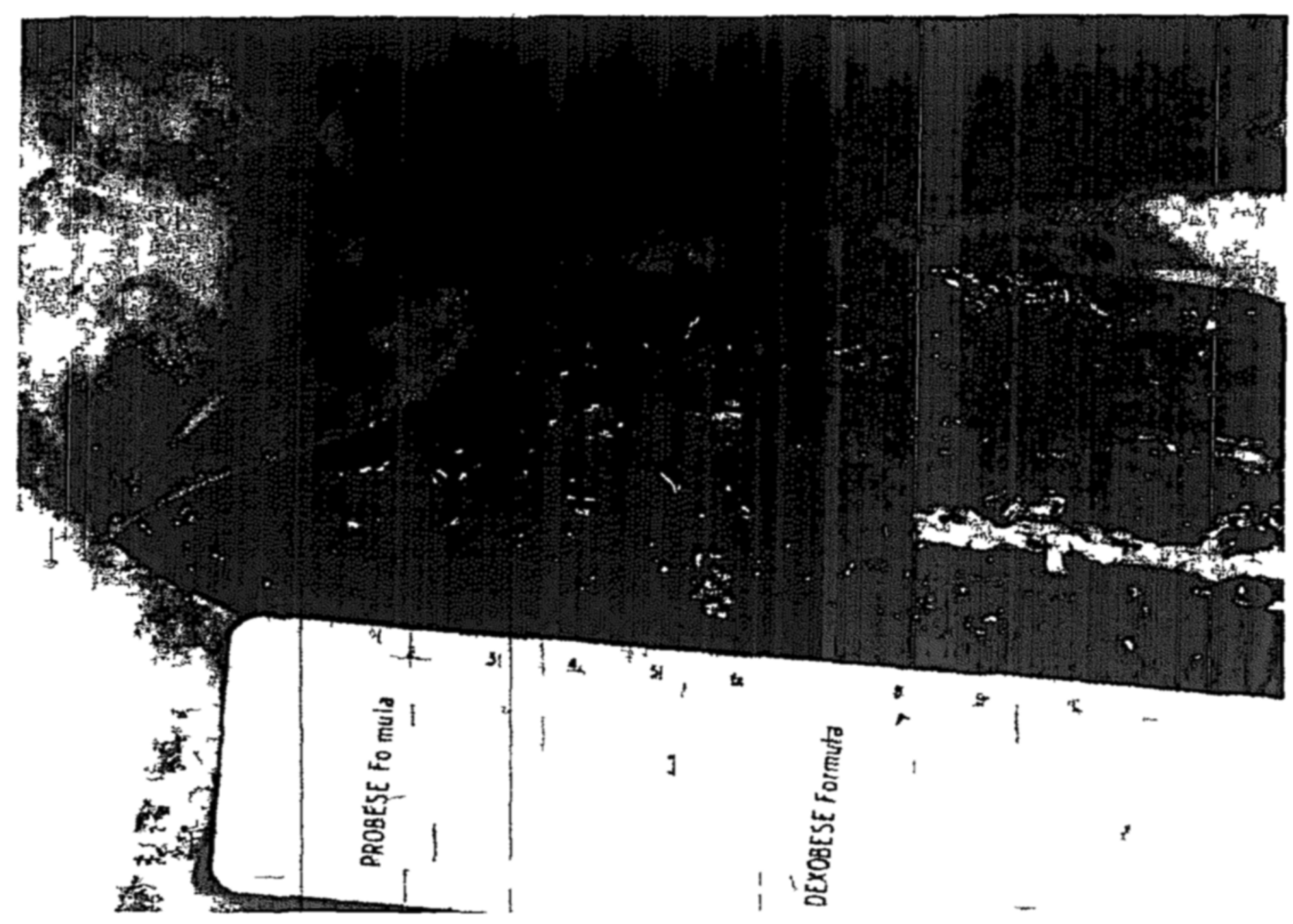

Figure 7 Autopsy dissection show ng p dural hremsto

an obstruction I used more force than I should have done and suddenly there was no resistance but blood came back in the tubing The block was abandoned and the repaur was completed under a relaxant and halothane with controlled and assisted respirations This repair was difficult for although muscular re laxation was adequate the wound was filled with dilated loops of bowel and bleeding was rather marked Cardiac arrest occurred suddenly as the dressing was being applied even though spontaneous respirations had seemed adequate 
The orotracheal tube was still in place and resuscitation measures were carried out immedrately, and the heart started with external massage, but it finally stopped even though the mesh was cut vertically to relieve abdominal tension The child died from respiratory and circulatory embarrassment secondary to increased intra-abdominal pressure from too tight a repair $F_{1}$ gure 7 is the photograph of the autopsy dissection of the site of the epidural This is what the pathologist said "On opening the vertebral arches there was an epidural haematoma found in the lumbar region $45 \mathrm{~cm}$ in size There was no subdural haematoma There was a congested liver and hyperaemia and oedema of the lungs, with partial atelectasis (especially in the lower lobes, bilaterally)" The complication of extradural haematoma is mentioned by Bromage where stilettes have been used to stuffen catheters ${ }^{3}$

There has been no total spinal anaesthesia in this series unless for the patient with intestinal obstruction who died However, in a previous report ${ }^{2}$ this occurred in two cases, but this was before suitable needles were avallable The hazard of inadvertent total spinal anaesthesia has been overemphasized in the literature ${ }^{67}$ It is an unnerving experience but should not cause alarm if it is recogntzed, and if equipment is ready to cope with it as it should be In the two cases mentioned, both infants were apnoeic for fifteen minutes, then tracheal tugging appeared, and finally full respirations returned in forty-five minutes, during this time oxygen was administered by mask

A complication which $\mathbb{I}$ wish to emphasize is from the same report "One infant nearly died from asphyxia while the block was being done when its head became flexed on the chest causing complete mechanical obstruction"

No cónvulsions were encountered in this series, moreover, those reported in the previous paper were due to overhydration or towic absorption from reduced strangulated bowel in gravely ill infants

\section{Discussion}

The opponents of paediatric epıdural anaesthesıa usually write from a wealth of experience in general anaesthesia, but with little or no familiarity with conduction anaesthetic techniques Statements are made, quoted, and requoted in the literature unt1l they become "Gospel Truths" I do hope that my observations are tempered by a certain amount of skill in most anaesthetic procedures Funthermore, my observations have been confirmed by other anaesthetists who are proficient in eprdural anaesthesia for infants and children, by our paediatricians, and by our surgeons Moreover, although the Children's Wing of the Hamilton General Hospital no longer attracts the admissions it formerly did because newer and finer facilities are avallable, yet paediatric epidural anaesthesia is being used increasingly in the other hospitals in the city Why, then, are we in this non-conformist position?

The anaesthetist is faced with the problem of providung relaxation and good exposure for abdominal surgery These conditions should not be obtained at the risk of the general well-being of the patient, who sequires a minimum of 
systemic change and a quick return to homeostasis Segmental conduction anaesthesia, alone or in combination with light general anaesthesia, has seemed to fulfil the requirements It has been stated that "with adequate anaesthesia and relaxation by any method, the muscles of respiration are inevitably affected and weakened "4 I do not believe this applies to epidural analgesia, for the primary innervation of the diaphragm by the phrenics should not be involved Clement A Smith says "Breathing is essentially diaphragmatic and abdominal in neonatal life, the thorax offering little more than a relatively fixed chamber into which the descent of the draphragm indurces the movement of air"8 Another important fact can be inferred since respirations are spontaneous, carbon dioxide levels are automatically controlled by the patient's breathing of air or a light anaesthetic mixture by a non-rebreathing valve This also explains why bleeding is frequently decreased

Prematures, neonates, and infants up to two weeks of age have shown varying degrees of atelectasis or faulty expansion In 1942 I was impressed by the work of Coryllos and Birnbaum on the aetiology of atelectasis ${ }^{9}$ They remarked on the rapidity with which oxygen and anaesthetı gases are absorbed from the lung distal to a bronchial obstruction, and the role of the nitrogen of the arr in preventing this Because of this it seemed a good idea to adapt epidural block to infants Geneial anaesthetics decrease respiratory efficiency except where respirators or farthful manual compression of the bag is practised The first has been impractical, and high flows of gases place the infant in an atmosphere which is highly absorbable so that the stage is set for increased atelectasis if it is already present, or for its development if the bronchial tree is obstructed by secretions With epidural block the patient can breath air, or a mixture of air, gas, and oxygen, and still be protected by the "mechanical bufler, nitrogen"

Recent investigations into the curculatory system of the infant have emphasized "central pooling," "increased peripheral resistance," etc I shall not go into this but shall simply say that the infant duffers markedly from the adult There is, however, a similarity too, for some infants show extremely high systolic pressures It is true that I did not report blood pressures in my early cases, because the readings were unreliable Since smaller cuffs have become avallable, blood pressures have been recorded I belıeve that halothane has stimulated the interest in blood pressures, for no other anaesthetic agent or technique has such an unpredictable effect on the circulatory system The charts shown in Figuies 8 and 9 are submitted to show that we are interested in blood pressures as a means of supervising the administration of an anaesthetac, but nt must be remembered that a blood pressure record is only one of several means of following the patient $s$ response to anaesthesia and surgery Colour, pulse, heart and breath sounds are all very rehable signs These charts also point out the difference between the circulatory reaction of the infant and that of the adult, for the infant does not show the characteristic falls of blood pressure that are observed in adults following a spinal or epıdural block involving the splanchnic outflow

I am sure all are agreed that any decrease in the curculating volume or a 
GH207 R61

\section{HAMILTON CIVIC HOSPITALS AHAESTHETIC CHART}

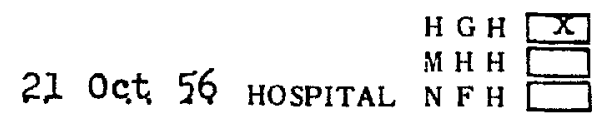

\section{RECORD OF PHYSICAL. EXAMINATION}

DATE TIME PULSE BP 710 RESPIRATION TEMPERATURE

\section{PHYSICAL EXAMINATION NEGATIVE EXCEPT FOR THE FOLLOWING}

Chest and heart neg. History of projectile vomiting. Tumour felt. Nutrition and hydration good. Weight $8 \frac{1}{2} 1 \mathrm{bs}$.

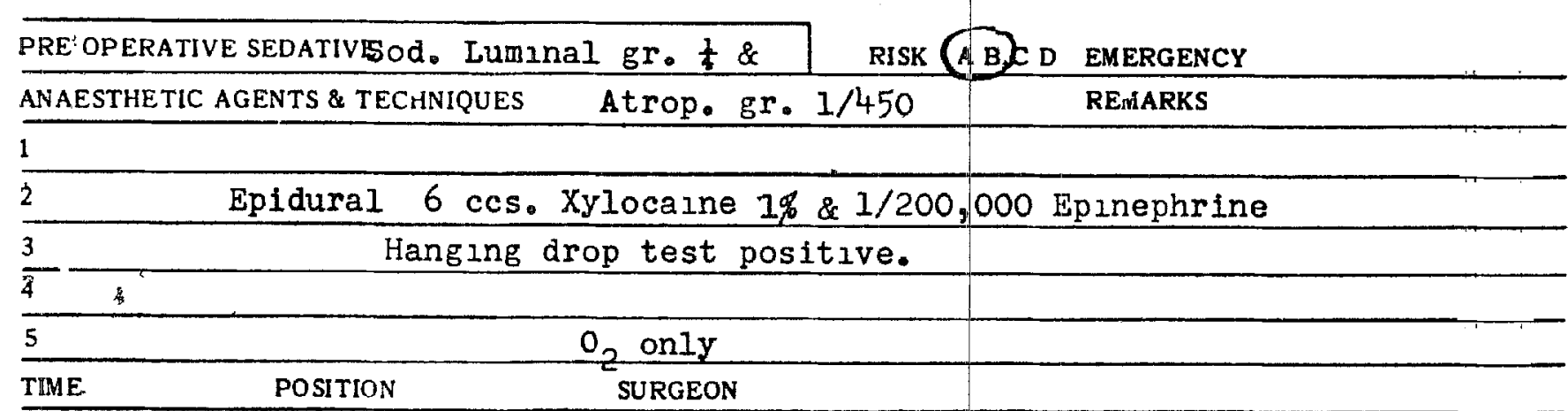

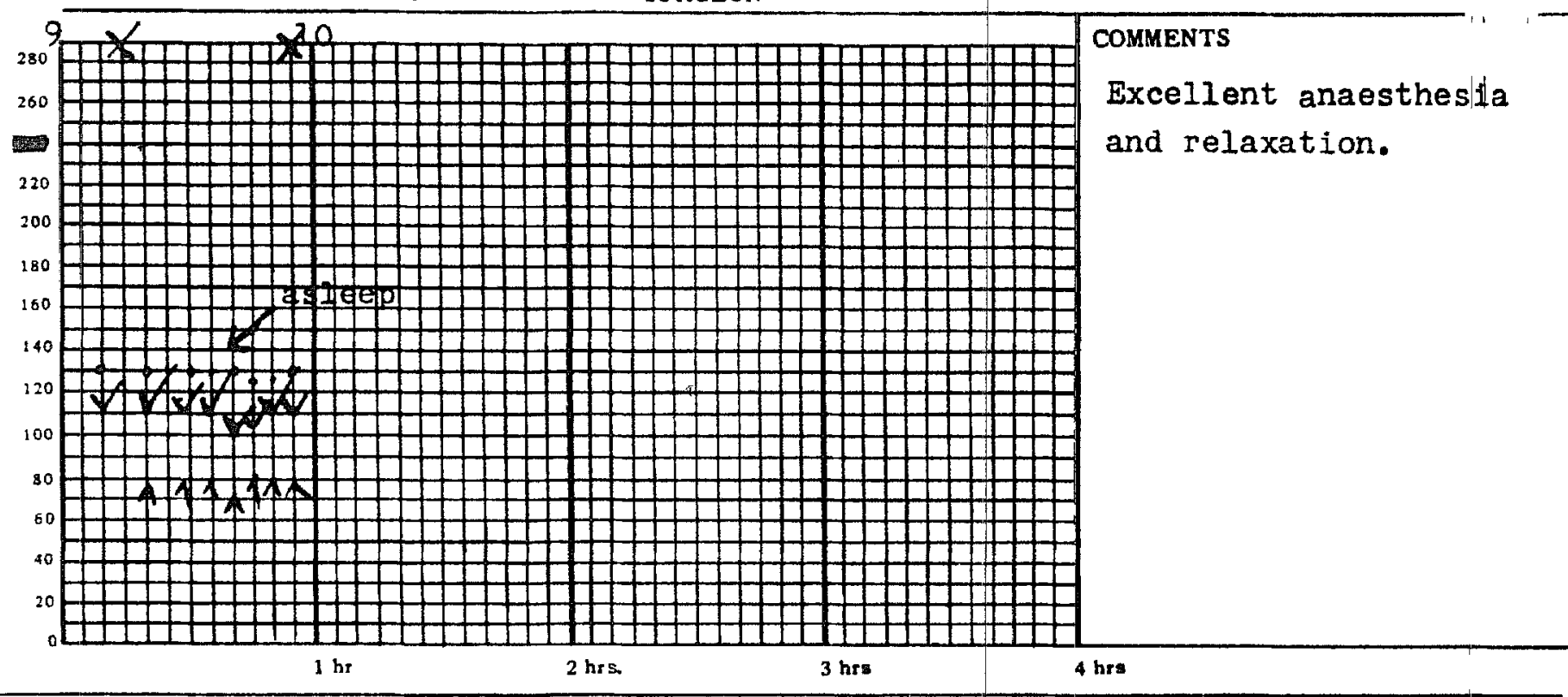

OPERATION PERFORMED
TOTAL OPERATING TIME $30 \mathrm{~m} 2 \mathrm{n}$.
DURATION OF ANAESTHETIC $40 \mathrm{~min}$. CONDITION ON LEAVING OPERATING ROOM ¿XCellent

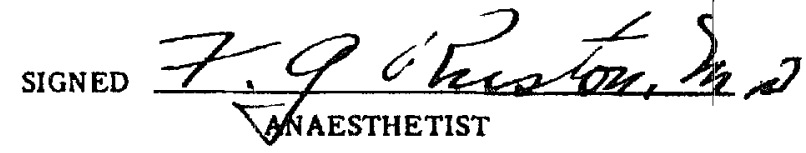

Figure 8

change in the electrolyte balance increases the anaesthetic risk by any technique Robert M Smith underlines this by saying

An additional claim is made that I beheve is false and dangerous, that is, that regional anaesthesia is indicated in toxic patients such as those with peritomitis and dehydration 
GH207 R61

\section{HAMHLTON CIVIC MOSPITALS AMABSTHETIC CHART}

DATE 15 0ct. 58 HOSPITAL NFH
PREOPERATIVE DIAGNOSIS Intussusception
PROPOSED OPERATION
Reduçtion

P. F \& months。

SURGEON Mighton

RLCORD OF PHYSICAL EXAMINATION

DATE BIME BULSE BP 120 RESPIRATION TEMPERATURE

PHYSICAL EXAMINATION NEGATIVE EXCEPT FOR THE'FOLLOWING

History of bloody stool. Intussusception confirmed by Barıum enema and

reduced by manipulation under flourciscopy. However as mass remalned

Datient was booked for laparotoing chest and heart neg, Wh 21 lbs. PRE OPERATIVE SEDATIVE Sod LumINol gr。 $\mathrm{r}$ \& RISK A BC D EMERGENCD

ANAESTHETIC AGENTS \& TECHNIQUES AtrOP. gr $1 / 450$ REMARKS

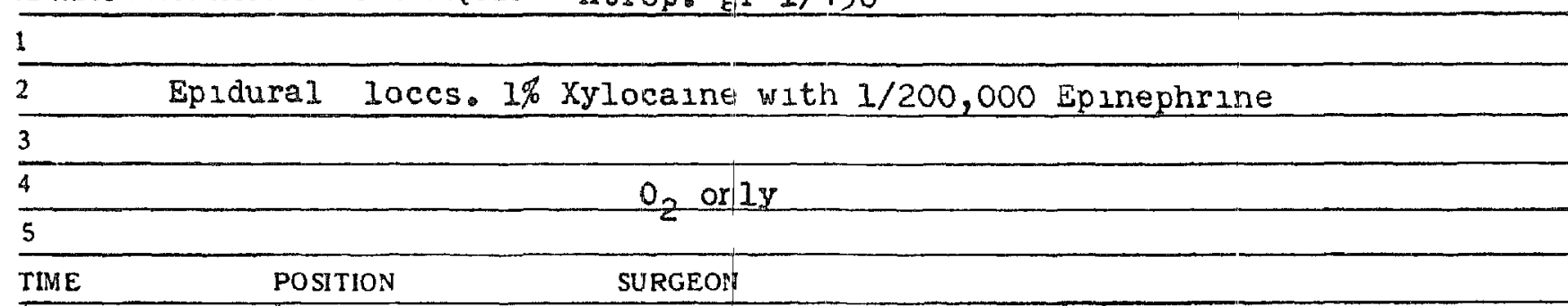

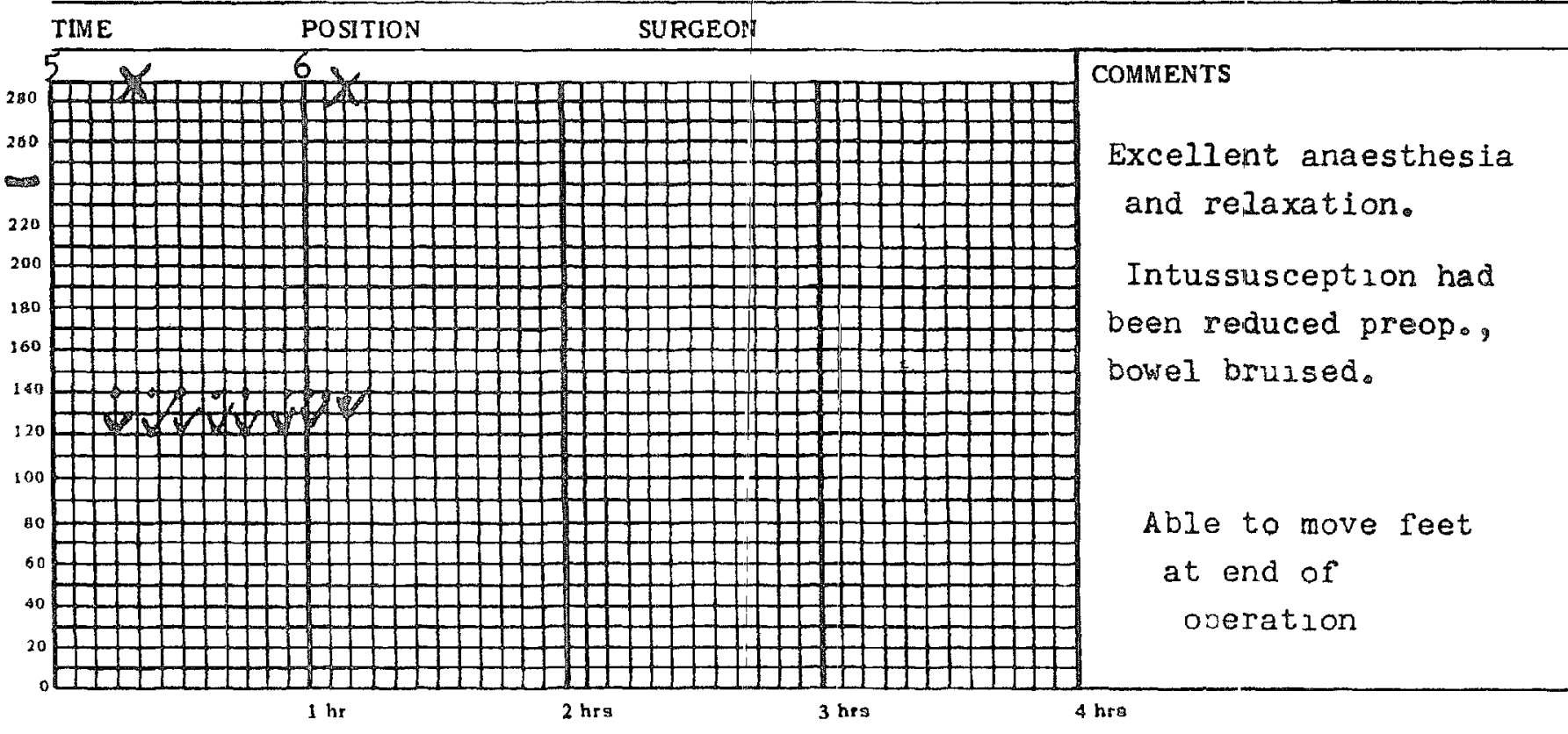

OPERATION PERFORMED Laparotomy plus appendectomy

TOTAL OPERATING TIME 40 mIn. DURATION OF ANAESTHETIC 50 man。 CONDITION ON LEAVING OPERATING ROOM gODd

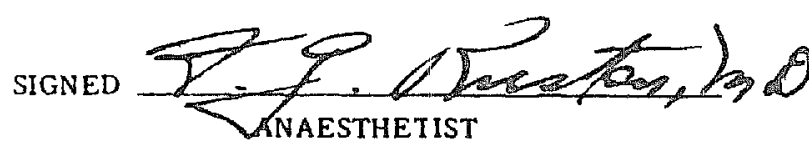

FigIURE 9

Ruston goes so far as to say that tmme need not be taken to hydrate such patients pror to anesthesia I am convinced that the use of regional anesthesia in sick patients with high fever and rapid pulse is dangerous and ill advised Such patients show decreased tolerance to local as well as general anesthetics Several experiences have confirmed this belief Any patrent who 1 s acidotic or otherwise critically $11 l$ should be fully prepared before receiving either regional or general anesthesia ${ }^{10}$ 
My statement, which he paraphrased, "In emergericy cases such as intestinal obstruction or appendicitis with ketosis, the operation need not be delayed until flund levels are restored," 2 is no longer valid I made it at a tume when fluid and electrolyte balance was not as well regulated as today Many patients were presented to the anaesthetist etther dehydrated or overhydrated However, the confidence in the epidural technique is expressed, perhaps too strongly, from personal observation I cannot leave this subject without saymg that I have never observed a heat convulsion under conduction analgesia but had it demonstrated under a general anaesthetic in a well-prepared three-year-old child with a perforated appendix Moreover, I am convinced that it is foolhardy to delay operation once the diagnosis of strangulated intestinal obstruction is made, for it is an unequal race to try to catch up on fluds, and can so easily end in irreversible shock But should such patients be subjected to a block? The recent report by Bornside and Cohn of the Department of Surgery of the Lousiana State University School of Medicine may give a clue They lound that "Pentoneal fluid from dogs with experimental strangulation intestinal obstruction was not lethal when injected into unanesthetized dogs This peritoneal fluid was lethal for dogs anesthetized with Pentothal Sodium "11

So much has been written regarding the difficulties encountered in epidural anaesthesia that some have been frightened away from its use The most difficult block is in the adult, for the dura is so easily punctured unless a large-bore short-bevel needle or a No 20 Wagner Point Needle is used Next to this gioup are the premature and newborn infants, but heie the dufficulty is to identify the interspinous space because of the rubbery texture of the subcutaneous tissue The easiest are in the older infants, e g pylonics, in which the subcutaneous tissue is decreased Let me repeat, the bogey of inadvertent total spinal anaesthesia has been exaggerated It is quite conceivable that this could result from a hasty injection or a laterally placed needle so that a lumbar nerve is pierced This has been discussed by Mostert, ${ }^{6}$ who showed that injection of $5 \mathrm{cc}$ of Lignocaine with methylene blue into a lumbar nelve of a dog one centumetre from the cord passed into the subarachnold space withn 15 seconds through the perineural spaces He uses this to emphasize the importance of a test dose II do not belneve in the five-minute wait to see if spinal anaesthesia develops, for it is more important to get a good cushron of fluid between the dura and the needle point so that movement cannot puncture the dura The necessity for placing the needle in the midline must be evident

Infants have an amazing tolerance to local anaesthetic drugs This has been observed in spinal anaesthesia, where relatively greatly increased dosage is required ${ }^{12}$ The same is true of epidurals, e $g$, an abdominal hysterectomy in an adult requires $25 \mathrm{cc}$, but a pyloric of 8 pounds needs $5 \mathrm{cc}$ Also the recovery time of respiration in the infants mentioned earlier was 45 minutes, whereas that of three adults who developed madvertent total spinal anaesthesia was well over two hours-both the infants and adults having received 2 per cent Xylocaine with epmephrinel No toxac reaction has been seen even when double the dosage was given in one case, when the first dose went into the muscle when the needle was moved Two cases of pyloromyotomy who received double the dose in error had 
some respuratory embarrassment from partıal' draphragmatic paralysis 'but normal respirations returned before the completion of surgery The dosage formula is only a rough gurde and is elastic An infant who has lost werght needs the full or an increased dose because of the relatively large frame, while the premature with its large head in proportion to its body requires less

Epidural block results in profound relaxation which can only be approximated by general anaesthesia with a relaxant, which does encroach on respiratory efficiency This is only part of the picture, for exposure and closure is more readily accomplished under a block As Macintosh says "Motor paralysis of the splanchnic nerves is revealed by the contracted tapelike gut, and this effect is

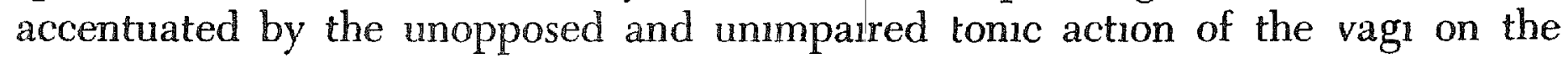
muscles of the intestinal wall "13 The same could apply to spinal anaesthesia if it were possible to control the level of anaesthesia in an infant I am sure this explains the statement of Leigh and Belton, ${ }^{12}$ when they consider spinal anaesthesia, that "In infants and young children, however, the surgeon may be disappointed with the continued distention of the bowel, in spite of well relaxed muscles" Our surgeons are unanimous in the opmion that the gut is contracted under epidural anaesthesia Moreover, it is interesting to see distention occur under continuous epidural anaesthesia if an additional dose of solution is delayed, and the return of constricted bowel within five minutes of injection

The following are some of the ways of keeping out of trouble if you are tempted to use epidural blocks in paediatric surgery, although the cynic mav say "Just don't ever even think about using such a techhique"

1 Never attempt epidural anaesthetic in an infant before you have used the method in a larger patient and have bult up some self-confidence

2 Reserve epidurals for procedures requiring good relaxation in premature or newborm infants, and for those who have a history of 1 espiratory complications or intestinal obstruction There is also a group requiring maximal relaxation for long perrods, eg, those undergoing abdominal permeal resections for Hirschsprung's disease

3 Sterle equipment and technque is essential If kits were used more often, the vials of anaesthetic solution should be included in them, for all can be autoclaved except those containing epmephrine

4 Proper positioning of the patient is important, especially in the sitting posture The head must be supported so that the alrway is not obstructed

5 A proper pre-anaesthetic check must be done-this includes history, physical examination, weight, seeing that gastic suction is working (pyloncs and those with intestinal obstructions have a large Levine tube in place prior to and durng operation), that cut-downs are running and have been started with large enough catheters, and that resuscitation equipment is in a ready state Absolute viglance should be practised

6 The recommended needles are excellent ( $F_{1 g s} 10$ and 11 ) They are the 2-inch No 22 gauge Becton, Dickinson meedles with added flanges, ${ }^{14}$ from the Special Anaesthetic List, catalogue No $466 \mathrm{LNR} H$ For the continuous method, the thin-walled No 18 needle with the Crawford Point is suggested, for it cairies the $\mathbb{B}-\mathrm{D}$ vinyl tubing, size VX020, and can be antoclaved 


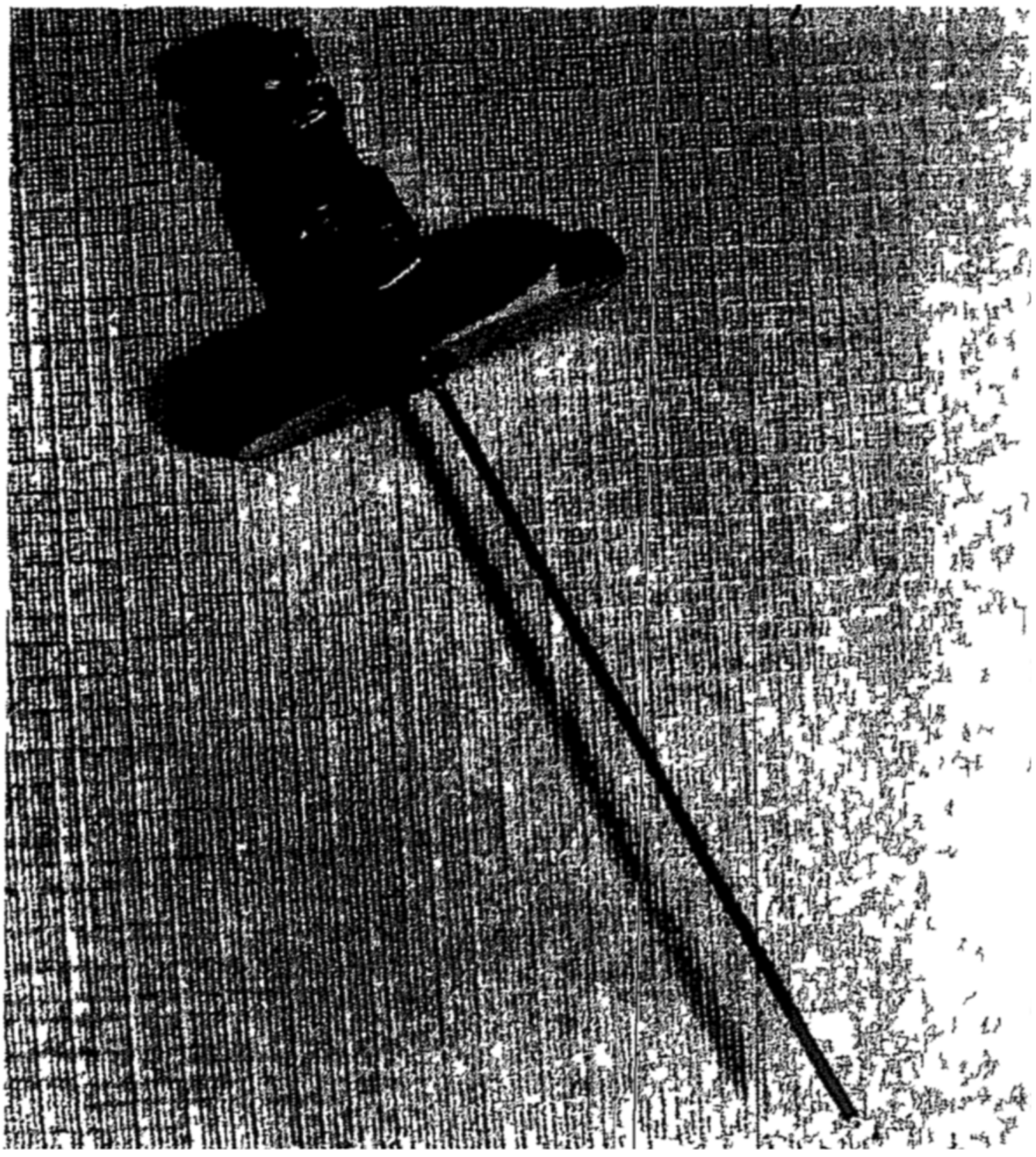

Figune 10 Epidural needle with Wagner Point modified, by flanges introduced by Stringer

7 The simplest method is the best for identifying the epidural space This is the hanging drop but if this test is not immediately positive rely on the loss of resistance

8 The following applies to continuous epidural blocks Always point the bevel cephalad and always inject some solution before passing the catheter into the needle Be sure the inner curve of the catheter faces cephalad and advance the catheter only 2 or $3 \mathrm{~cm}$ beyond the needle point so that it will not run along a nerve tunk ${ }^{3}$ Never withdraw or rotate the catheter while the needle is still in place-this will prevent the loss of a tip by shearing Never use force to advance the catheter (see $F_{1}$ i 7!)

9 Extreme care must be used if the patient is placed in a head up position during and after surgery An order is written to keep the patient flat for two hours postoperatively which allows for the complete return of muscle tone and the drsappearance of the sympathetic block

In conclusion let me leave the following thoughts with you It is admitted that general anaesthesia techniques have evolved to a state of excellence but there stull 


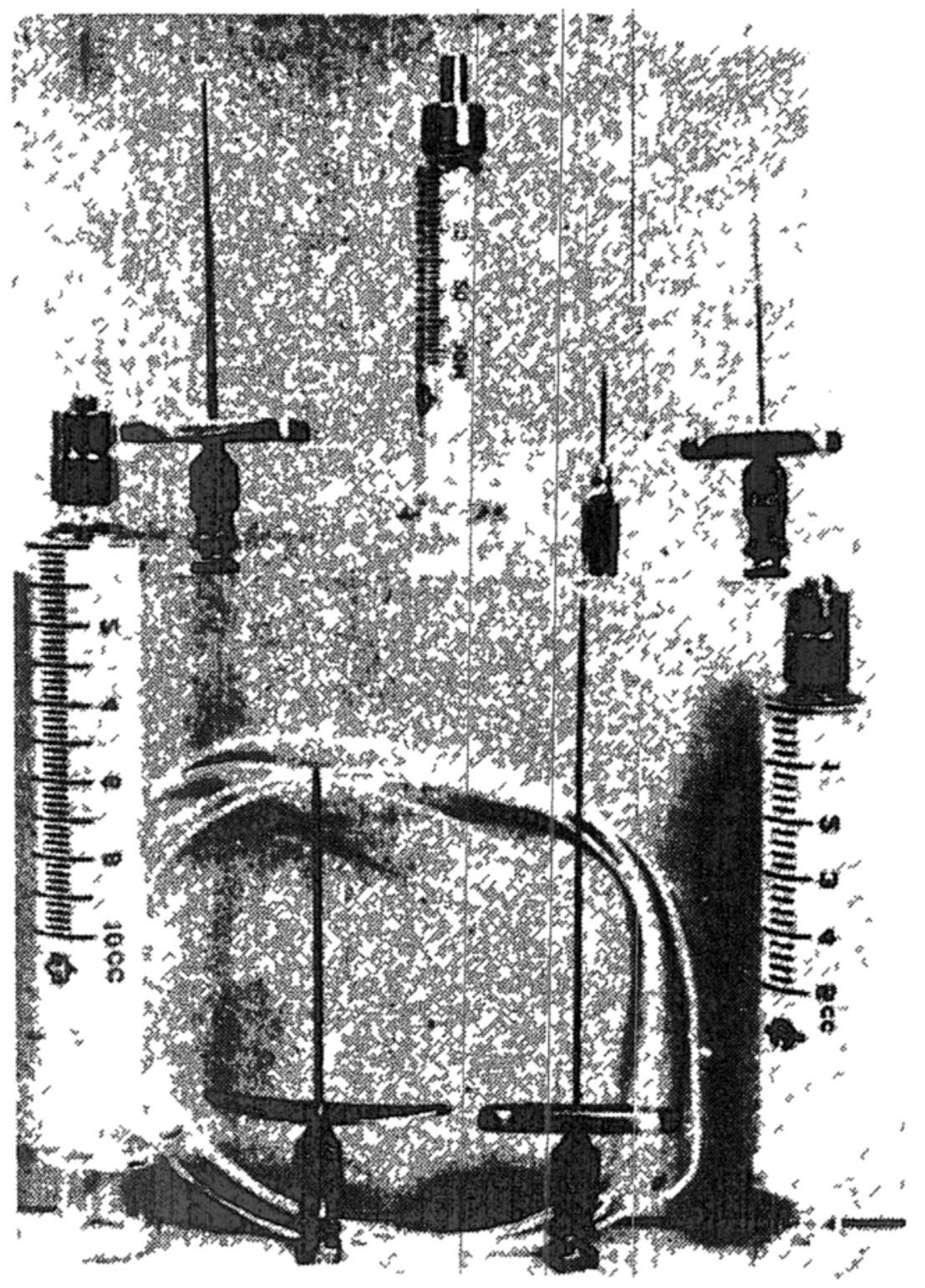

Figure 11 Continuous epidural kit with vinyl catheter and thin-walled No 18 needle (lower left)

remain the problems attendant on intubation, carbon dioxide build-up, resistance in gas machines, toxic reactions from andesthetic agents, and unprediciable results from relaxants On the other hand, conduction anaesthetic techniques were introduced at a time when local anaesthetic drug', such as cocaine and novocame were undependable and even fraught with danger to the patient But today these techniques are unpopular even though we have such excellent needles and superb local anaesthetic solutions I am perplexed at the hesitation, or perhaps more correctly, disinterest that is shown towasds all conduction anaesthesid for paediatric surgery Often it is looked on as a "parlour trick" I would not have it otherwise unless the whole team of surgeon, paediatrician, and anaesthetsist have confidence in the application of epidural techniques to paediatric surgery

\section{SUMMARY}

The role of epidural anaesthesia in paediatric surgery is presented as a continuation of the prellmmary reports which were published in 1954 and 1957 The 
technique of epidural block has been modified by the advent of Carbocame and Nesacaine so that Xylocaine is no longer in a singular position The introduction of the modified Wagner Point needle has added greatly to the safety and facility of epidural block Continuous epidural anaesthesia has been used in prolonged serious abdominal operations $\mathrm{A}$ reply has been attempted to the criticism of paediatric epidural anaesthesia Safety measures have been emphasized The author believes that although epidural anaesthesia can hold a position in the practice of paediatric anaesthesia, yet it should not be used unless all the members of the surgical team have confidence in its application

\section{RÉSUME}

Dans deux artıcles antérneurs, ${ }^{12}$ nous avons parlé de l'usage de l'anesthésie épıdurale en chirurgie pédiatrıque Le but du présent travall est d'abord de farre part de notre expérience dans ce domaine à l'hôpital Général de Hamilton, depurs la publication des articles mentionnés, puis de démontrer pourquoi nous croyons que cette technıque possède une place bien déterminée en anesthésıe pédiatıque et enfin d'essayer de dissiper quelques-uns des doutes qui ont condurt à l'énoncé suivant concernant l'anesthésie pour les pylorotornies "l'opportunité d'utiliser l'anesthésıe épıdurale nous laısse sceptıques" 4

Il existe deux technıques l'une à dose unique pour la chırurgie abdominale d'une durée inférneure à deux heures, et l'autre, à doses multıples, appelée également épidurale continue pour la chirurgie abdommale chez des mallades de plus de tross mois dont lopération doit durer plus de deux heures $\mathrm{A}$ ces deux méthodes, on peut ajouter du thiopentone ou un anesthésique général (un tube orotrachéal peut être mis en place si nécessaire)

Chez les prématurés et les tout petits, on fait le blocage sans anesthésie, l'enfant etant en position assise, pendant qu'un assistant luı tient fermement les coudes et les genoux, et que la tête du malade est supportée de façon à ce que la colonne vertébrale sort légèrement fléchie Nous suggérons une argulle $\mathrm{N}^{\circ} 22 \mathrm{BD}$ Wagner Point, porteuse d'alerons Pour identifier l'espace épıdural, nous utilısons le signe de la goutte pendante, mais sı cette épreuve ne s'avère pas positive ımmédiatement, nous utılısons celle de la perte de résıstance La technique de l'épidurale contınue née peut être appliquée que chez les enfants de plus de trois mois, parce que nous uthlısons une arguille $N^{\circ} 18$ à paror mince, à travers laquelle nous passons un tube $\mathrm{BD}$ en vinyl (tube qui peut être stérilssé à l'autoclave) et quı mesure $\mathbb{N}^{0} \mathrm{~V}$ x 020 Il faut agir avec douceur, le passage du tube peut être facllté par l'injection de 2 ou $3 \mathrm{ml}$ de la solution anesthésique Il ne faut pas retirer ou tourner le cathéter pendant que l'arguille demeure en place Le cathéter dort dépasser le bout de l'arguille de deux centumètres seulement et, une fois qu'on a returé l'argulle avec som, on fixe le cathéter au dos avec du diachylon et l'on adapte à l'extrémité distale du cathéter la serıngue contenant la solution anesthésique, et munie d'une argulle hypodermique

Pour les deux techniques, le calcul de la dose se fait d'après la formule

$$
1 / 2 \text { (poids en livres) plus 范 ou } 1 \mathrm{ml}=\text { dose en } \mathrm{ml}
$$


Nous avons utilssé les substances survantes Xylocame 1 pour cent et 15 pour cent avec de l'épınéphrme 1/200 000 et de la cas bocame 1 pour cent à 15 pour cent, les deux mélanges assurent une anesthésie de deux heures La Nésacaine à 2 pour cent a été suffisante pour des pylorotomies d'une durée de 35 minutes et pour donner des doses additionnelles au cours d'anesthésies épidurales continues

Les tableaux c1-contre parlent d'eux-mêmes et font vorr l'usage que nous avons fart de cette technique à l'hôpital Général de Hamilton Le tableau I représente une copie de la feulle d'anesthésie remplie au cours d'une hémıhépatectomie pour un tératômemalın Les tableaux 2, 3 et 4 montrent le problème de la réparation secondaire d'un omphalocèle important

Le tableau $\mathrm{V}$ montre l'anesthésie pratıquée pour une résection abdominopérméale pour une maladıe de Hnschprung, et le tableau VI détalle l'anesthésie farte pour une deuxième opération le déplacement de la colostome parce que l'anastomose au rectum avait cédé

Le dermer cas d'anesthésıe épıdurale combinée.tut pratıqué pour la résection abdomino-périnéale d'un neuroblastome Cet enfant est mort 18 heures après l'opération d'une hémorragie méconnue et d'une aspiration terminale

Les complications ont été peu nombieuses Il est survenu une mort immédiatement après le blocage chez un nouveau-né moribond souffrant d'une obstruction intestinale Nous n'avons pas eu d'autopsie, la cause de la mort n'a pas eté établı mass, sans aucun doute, l'anesthésie a été une cause adjuvante Une autre comphcation non mentionnée dans le tableau II a consisté en un hématome épıdural (figure 7) découvert à l'autopsıe, ll s'agıssait de réparer un omphalocèle important rupturé sous anesthésıe générale avec usage de myorésolutıfs parce que le blocage épidural continu a dû être abandonné à cause d'une hémorragie provoquée par la mise en place du cathéter mise en place trop violente La mort est survenue à la surte d'un arrêt cardıaque occasıonné par des troubles respiratorres et circulatorres due à une réparation trop serrée $\mathbb{L}$ a complication signalée dans un artıcle antérieur-l'asphyxie-est survenue parce que l'assistant a lasssé la tête en flexıon produssant ansı une obstruction mécanıque des voses respıratorres

Nous fassons valoir les raisons qui nous ont incités, icı à Hamilton, à contunuer d'employer l'épıdurale en pédıatrie L'anesthésie générale, inévitablement dımınue l'efficacité respiratorre, qu'on y ajoute ou non des myorésolutifs Au cours de l'anesthésie épıdurale, cela ne devrait pas exister, cal les phrénques ne sont pas touchés et, chez les nouveaux-nés, la respiration est essentsellement diaphragmatıque et abdominale De plus, sous anesthésie régionale la respiration spontanée iègle le tau de gaz carbonıque, ce qui explique la diminution du suntement sanguin

Les enfants souffrant d'atélectasie pulmonane ou de troubles de l'expansion pulmonare peuvent respirer de l'arr sous anesthésıe épidurale et l'azote de l'au devient une protection contre l'expansion de l'atélectasie en empêchant les parois des alvéoles aérés de s'accoler

Les tableaux VIII et IX répondent aux cintiques contre le fart que les pressions at ténelles n'ont pas été prises De plus, chez les enfants, on observe une stabilité 
des pressions artérielles, alors qu'au contraire chez les adultes, sous antsthésie ıachidıenne ou épıdurale atteıgnant les segments splanchnıques, on peut prédire presque à coup sûr les chutes abruptes de la tension artérielle

La critique que faisait Robert M Smith, dans un article antérieur, était justufiable, cependant, il ne faut pas oublner que, aujourd'hui, chez nos malades, léquilibre des liquides et des électrolytes est mieux fart Sans doute, il faut prendre le temps de rétablır cet équilıbre à moins qu'il ne s'agisse d'une obstruction intestinale par étranglement où tout retard à l'opération pourratt aboutrr à un état de choc urréversible

L'anesthésie épıdurale devient avantageuse chez les malades de cette catégonie La justıficatıon de cela peut ètre prise dans le travall de Cohn et Bornside qui ont trouvé que sı l'on injectait à des chiens de l'exsudat péritonéal d'autres chiens morts par obstruction mécanıque expérımentale, ils survivaıent, maıs ceux qui étàient anesthésiés au thiopentone pour cette injection mouraient

Les difficultés citées dans la littérature au sujet de l'anesthésie épıdurale ont contribué à empêcher l'usage de cette méthode On a insisté sur le blocage rachidien total, accidentel, si l'ơn en fait le diagmostic, il ne devrait pas constituei un problème sérneux On peut éviter ce blocage en plaçant l'angulle sur la ligne médiane, autrement l'arguille peut traverser une racine nerveuse et permettre à la solution anesthésıque de pénétrer dans l'espace sous-arachnoıdıen par les trous périneuraux Nous ne recommandons pas $/$ la dose d'essar et l'attente de cinq minutes, car il est préférable d'obtenir un manchon de solution entre la pointe de larguille et la dure-mère Ce qui est essentiel, ce sont la vigılance et une préparation adéquate

La tolérance des enfants pour les anesthésiques locaux est étonnante Nous $\mathrm{n}$ avons pas observé d'effets toxiques avec des doses doubles de la normale Il est survenu accıdentellement chez deux enfants des anesthésıes rachıdıennes totales (depuis le rapport prélıminarre), elles ont entraîné de l'apnée suivie, au bout de 15 minutes, par de la traction inspiratone du maxillaure inférıeur et, après 45 minutes, d'un retour complet de la respiration Trois adultes, chez qui la chose est survenue, sont demeurés en apnée durant plus de deux heures

Sous bloc épıdural, la chirurgie est plus facile car le relâchement abdominal est complet, mass ce qui est plus important, c'est que l'intestm est comme un ruban et en constriction à cause du blocage de linnervation sympathique, ce qui leve le frem de l'action parasympathique sur l'intestan (à la condition que le blocage s'étende aux segments splanchniques)

Nous avons fart neuf recommandations pour augmenter la sécurité des techn1ques épıdurales en chirurgie pédiatrıque Finalement, les problèmes se rattachant a l'anesthésıe générale sont mentionnés afin de chercher à savoir pourquoi l'anesthésıe par conduction est-elle négligée à ce point en ảnesthésie pédiatrique, alors que nous avons à notre disposition de si belles argulles et de si bonnes solutions anesthésiques En dépit de tout cela, je n'agirass pas autrement, pourvu que toute l'équipe constıtuée du chirurgien, du pédiâtre et de l'anesthésiste at confiance à l'indication de l'anesthésie épidurale pou la chrrurgie de l'enfant et du nour eau-né 


\section{REFERENCES}

1 Ruston, F G Epidural Anaesthesia in Infants and Children Canad Anaesth Soc I 137 (1954)

2 - Epidural Anesthesia in Pediatric Surgery Anesth \& Analg 3676 (1957)

3 Bromage, $P \mathbb{R}$ Spinal Epidural Analgesia Edinbuigh and London Livingstone (1954)

4 Cons, A W Anaesthessa for Pyloromyotomy in Infancy Canad Anaesth Soe J 1018 (1963)

5 Wagner, $\mathbb{R}$ S A Needle for Single Dose Perldural Anesthesia Anesth \& Analg 3631 (1957)

6 Mostert, J W Unintentional Spread of Epiclural Anaesthesia Brit J Anaesth 32334 (1960)

7 Morrow, W F K Unexplained Spread of Epıdural Anaesthesı Brit J Anaesth 31359 (1959)

8 SmITH, C A The Physiology of the Newborn Infant, 3rd ed Springfield, Ill Charles C Thomas (1959)

9 Corylios, $\mathrm{P} N$ \& Bringaum, $\mathrm{L}$ L Studjes in Pulmonary Gas Absorption in Bronchial Obstruction, The Theory of Air Absorption in Atelectasis Am J Med Sc1 $183 \quad 347$ (1932)

10 Smith, $\mathbb{R} M$ Anesthesia-for Infants and Children, Ist ed St Lours Mosby (1959)

11 Bonnsme, $G$ H \& CoHn, $T$ The Toxicity of Flund in Strangulation Obstruction The Influence of Anesthesia Surgery 49606 (1961)

12 Leigh, $M$ D \& Berron, $\mathbb{M}$ Pediatric Anesthesia, 1st ed New York MacMillan (1948)

13 Macintosin, $\mathbb{R} \mathbb{R}$ Lumbar Puncture and Spinal Analgesı Edıburgh Livingtone (1951)

14 Stringer, $R$ M Epidural Anesthesia with Xylocane Anesth \& Analg 33 195 (1954) 